\title{
The Effect of Corporate Social Responsibility on Customer Loyalty in Mobile Telephone Companies
}

\author{
Submitted 25/08/19, $1^{\text {st }}$ revision 18/09/19, $2^{\text {nd }}$ revision 28/10/19 accepted 20/11/19
}

\author{
Efstathios Dimitriadis ${ }^{1}$, Eleni Zilakaki ${ }^{2}$
}

\begin{abstract}
:
Purpose: The present study aims at developing and empirically testing a research model that presents the influence of Corporate Social Responsibility on corporate image, customer satisfaction and customer loyalty, demonstrating the direct and indirect effects among these structures.

Design/Methodology/Approach: The examination of the proposed research model was carried out using a structured questionnaire completed by 358 mobile users in the city of Kavala. The validity and the reliability of the questionnaire were examined, while for the data analysis the Structural Equation Modeling Technique was used with LISREL 8.80.

Findings: The findings of this study indicate that Corporate Social Responsibility have not a significant direct effect on customer loyalty, while corporate image and customer satisfaction have a significant positive effect on customer loyalty. Moreover, the findings provide practical new insights in understanding how a mobile company's CSR policy could be developed and implemented to help enhance customer loyalty through the mediating effects of customer satisfaction.

Practical Implications: The companies would like to understand the implications of its CSR policy implementation, especially in enhancing its corporate image and customer satisfaction in terms of reputation and impression.

Originality/Value: This study is a pioneer research in addressing the mediating role played by customer satisfaction for strengthening the relationship between CSR and customer loyalty in mobile phone companies.
\end{abstract}

Keywords: Corporate image, customer satisfaction, confirmatory factor analysis, Structural Equation Models.

JEL codes: $M 14, C 12, C 38$.

Paper type : Research article.

\footnotetext{
${ }^{1}$ Corresponding author, International Hellenic University - Kavala, Department of Management Science and Technology, edimit@teiemt.gr (edimit@mst.ihu.gr)

${ }^{2}$ International Hellenic University- Kavala, Department of Management Science and Technology, e_zilakaki@yahoo.gr
} 


\section{Introduction}

Mobile phone companies have been dynamically invading the lives of citizens in recent decades. Furthermore, belong to one of the fastest-growing industries in the world of business and have more than five billion users. Companies provide telecommunication and information services, including voice and text messaging (SMS), internet access, image and video messages and other data services, to $90 \%$ of the world's population. Because of the ubiquitous of mobile phones, mobile service providers can play a key role in shaping a more sustainable society (Anthony et al., 2011).

The rapidly changing rhythm of technology has transformed the use of mobile phone services from luxury into mass consumer market. Mobile phone companies are constantly competing with each other. Customer loyalty is the factor that plays an important role in ensuring their sustainable growth (Turnbull et al., 2000). How to develop and achieve customer loyalty has thus become a critical issue for mobile phone companies under a highly competitive business environment.

Another critical issue for mobile phone companies is how to form their CSR. This CSR fulfillment is required to comply with economic, environmental and social concerns and respond to the expectations of stakeholders on environmental and social issues. The CSR is framed around the responsibility of the companies as regards the local communities and the society in general. The demands for the corporate social responsibility have increased in time as the social expectations have changed and at present incorporate a broad genre of social, environmental and financial issues. The accomplishment of these demands obliges the companies to proceed voluntarily beyond the minimum regulatory compliance (Fordham et al., 2018). The adoption of practices of CSR in business can influence the concerned parts positively (including the consumers, the employees, the investors, the community) and the environment (Moktadir et al., 2018). By integrating CSR as a policy into core business strategies, CSR enables companies to enhance their competitive advantage that differentiates themselves from their competitors and maintain sustainable relationships with their stakeholders. Implementing a CSR policy is thus important and essential to sustainable operations and long-term development of a company (Chang and Yeh, 2017).

Mobile phone companies are taking initiatives to develop CSR policy in order to take up its business. More specifically, all five mobile service industries operating in Greece and addressed in this study, have recently implemented their CSR policy and are actively engaged in CSR activities to promote their corporate image and enhance their competitive advantage. The total CSR commitment of the companies was the cause of this study to examine the possible outcome of CSR policy in customer loyalty in mobile phone companies. As part of the services offered by mobile phone companies, the attractiveness of a business can grow when it meets the high emotional needs of customers as well as their operational needs. CSR may be the 
answer of a mobile phone company to meet these needs when the company's image is environmentally friendly and socially responsible. Therefore, in order to help mobile phone companies understand better the practical implications of their CSR policy, we propose a new research model to look at the relationship between CSR and customer loyalty within the mobile phone companies.

\section{Literature Review}

The term Corporate Social Responsibility was initially used by two teachers at Harvard University, Adolf Berle and Gardiner Means in 1932, in their book entitled "The Modern Corporation and Private Property". Even if the concepts of corporate social responsibility emerged in the 1930s, a characteristic term was mentioned for the first time in 1953 by Howard Bowen in his book "Social Responsibilities of the Businessman". Ever since, the idea of corporate social responsibility has occupied the world of business, contributing to the financial, social and environmental development as well as to benefits which concern all interested parts. Some of the most important facts of corporate social responsibility regard human rights, corporate management, health, security, the environmental effect, working conditions and the contribution of all these components in the economic development (Moktadir et al., 2018).

At the same time, the adoption of corporate social responsibility is connected to the long term viability, value and success of the companies (Whait et al., 2018). The businesses are expected to meet the financial, legal, ethical and philanthropic expectations of society in which they are operating. Moreover, they are expected to apply a wide spectrum of corporate social responsibility practices, such as the protection of the environment, the management of personnel, the responsible management of the supply chain, charity donations, customer liabilities, the development of society, the climate of professional security and the moderation of the dangers (Lau et al., 2018).

According to Kadlubek (2015), there are four dimensions of corporate social responsibility which are the following: Economic Dimension, Legal Dimension, Ethical Dimension and Philanthropic Dimension Corporate social responsibility is a fundamental element of corporate marketing strategies and customer loyalty is seen as a vital goal for the survival and growth of a business. By creating a loyal customer base, you develop a sustainable competitive advantage (Kotler and Amstrong, 2008). Customer loyalty is one of the most representative ways in which consumers express their satisfaction with corporate performance. At the same time, it is closely linked to the profitability of the companies (Garcia de los Salmones et al., 2009). Customer loyalty is predicted by the customer's attitude and intentions towards the service offered and the repetitive purchasing behavior. A complex approach to measuring consumer loyalty involves incorporating the dimensions of attitudes and behaviors and has been extensively used in the literature on the study of consumer loyalty (Aramburu and Pescador, 2019). 
Over time, researchers have studied the impact of corporate social responsibility on customer loyalty. Customer loyalty is one of the most meaningful customer behaviors that businesses want to influence through the use of corporate social responsibility as a marketing tool. Some researchers question the direct relationship between corporate social responsibility actions and consumer loyalty (Lombart and Louis, 2014). However, empirical studies incorporating corporate social responsibility into customer loyalty models have shown a positive relationship between these two concepts (Stanaland et al., 2011; Mandhachitara and Poolthong, 2011; Ailawadi et al., 2014; Chung et al., 2015).

The main result of positive corporate social responsibility activities is positive word of mouth advertising and the recommendation for a socially responsible company, which is a key aspect of customer loyalty (Chang and Yeh, 2017). The higher the level of corporate social responsibility initiatives, the stronger the customer's identification, assessment and dedication to the company ( $\mathrm{Lu}$ et al., 2017). Moreover, the study of Arikan and Güner (2013), has shown that corporate social responsibility also has a direct impact on customer loyalty.

The perceptions of corporate social responsibility are an important source of customer satisfaction (Xie et al., 2017). As a psychological condition, satisfaction is a phenomenon that is not immediately observable, since it does not provide either a clear feeling or a clear cognitive assessment. It incorporates both cognitive and emotional processes. Satisfaction is also relevant in the sense that it is based on a process where the customer's subjective experience will be compared with an initial reference point (Swaen and Chumpitaz, 2008). In marketing literature, customer satisfaction was recognized as an important part of corporate strategy and a key driver of stable long-term profitability and market value (Luo and Bhattacharya, 2006).

Corporate social responsibility efforts can improve customer satisfaction by increasing the usefulness and value of a business (Perez and Rodriguez del Bosque, 2015). Customers are likely to develop a strong relationship with a socially responsible company through corporate social responsibility activities, thus having a better perception and therefore greater satisfaction with the products or services provided by the company (Chang and Yeh, 2017). For this reason, Qu (2014), argued that corporate social responsibility has a strong positive impact on customer satisfaction. Also, Yuen et al. (2018), claimed that CSR activities have a varied influence on satisfaction.

Based on these views, Luo and Bhattacharya (2006), argue that customers are likely to be more satisfied with the products and services offered by socially responsible businesses. Their findings reveal not only that there is a direct link between corporate social responsibility and customer satisfaction but also that customer satisfaction is fully mediated by the relationship between corporate social responsibility and stable market value. In a similar context, $\mathrm{He}$ and $\mathrm{Li} \mathrm{(2011),}$ 
examine this relationship in the mobile telecommunications sector and find that corporate social responsibility has a direct impact on customer satisfaction. Additional empirical studies have also shown that corporate social responsibility associations affect customer satisfaction (Galbreath, 2010; Mandhachitara and Poolthong, 2011; He and Li, 2011; Loureiro et al., 2012; Martinez and Rodriguez del Bosque, 2013).

The corporate image is a common view that stakeholders perceive about an organization and is considered an important factor in organizational legitimacy. Businesses can use different strategies to improve their image and the involvement of corporate social responsibility is one of the most important ways of building such a picture (Vilanova et al., 2009; Galbreath, 2010). The corporate image is based on the collective impressions of a company's customers. These impressions come in part from four reasons: a person's personal contacts with the business, reputation acquired by the firm, mass media, psychological predispositions not controlled by the company. Perhaps the reason why the corporate image is of interest to managers is that it offers a competitive basis that is very difficult to imitate by competitors. Perhaps the reason why the corporate image is of interest to managers is that it offers a competitive basis that is very difficult to imitate by competitors (Liu and Zhou, 2009).

Numerous studies have been conducted on the significant positive causal link between corporate social responsibility and corporate image. Research models show that corporate social responsibility activates the process of creating a corporate image (Arendt and Brettel, 2010). Da Giau et al. (2016) and Macchion et al. (2018), found that corporate social responsibility positively affects consumer ratings of companies and products or services. At the same time, Fatma et al. (2015), demonstrated that corporate social responsibility initiatives are successfully strengthening the positive corporate image in the minds of customers. In addition, Lai et al. (2010), provided evidence on the belief that corporate social responsibility has a significant positive impact on the company's image. Branco and Rodrigues (2006), also confirmed that corporate social responsibility activities positively enhance the image of an enterprise by all stakeholders, including investors, customers, employees and competitors. At the same time, Mubarak et al. (2018), examined the effectiveness of corporate social responsibility in creating and enhancing corporate image by focusing on corporate charity and found that charitable activities lead to improvements in corporate image and enhancement of the relationship with the community.

In addition, several other studies have found the positive influence of corporate social responsibility on the corporate image (Gupta and Pirsch, 2008; Arendt and Brettel, 2010; Hossain et al., 2016), which in turn has a mediating effect on purchasing decisions (Huang and Lien, 2012; Huang et al., 2014). This result leads to benefits such as greater customer trust in products or services and higher revenues of a company (Stanaland et al., 2011; Huang et al., 2014; Servaes and Tamayo, 
2013; Pang et al., 2018). Therefore, companies can use corporate social responsibility initiatives as a tactical tool to create a positive image that in turn differentiates businesses from those of competitors (Hsu, 2012).

Consequently, corporate social responsibility efforts can help businesses improve their customer satisfaction by attracting and retaining them (Xie et al., 2017), to enhance their corporate image (Lee and Heo, 2009) as well as to increase customer loyalty (Bolton and Mattila, 2015). Based on the views outlined above, the following hypotheses are proposed:

H1: Corporate social responsibility has a positive impact on the corporate image.

H2: Corporate social responsibility has a positive impact on customer satisfaction.

H3: Corporate social responsibility has a positive impact on customer loyalty.

The corporate image is defined as the net result of all experiences, impressions, beliefs, feelings and knowledge that people have about a company (Minkiewicz et al., 2011). Lee and Lee (2018), identified the corporate image as the overall impression of customers for a company represented by its products or services. At the same time, Srivastava and Sharma (2013), defined the corporate image as the set of impressions through which a product or service is known and through which people describe, remember and relate to it. According to this view, the corporate image concerns the image associated with the name of an organization. The corporate image consists of two dimensions. The functional and emotional dimension. The functional dimension concerns the most tangible or real properties such as reputation, quality of service and the capabilities of a company. The emotional dimension is related to the subjective feelings and impressions of a company's clients (Chang and Yeh, 2017).

Some marketing scholars suggest that the corporate image may affect the purchasing decision of consumers. In this context, the corporate image becomes a matter of attitudes and beliefs about customer satisfaction. A general assumption is that a favorable corporate image has a positive impact on consumer behavior towards products or services. In recent years, some empirical studies have examined the impact of corporate image on customer satisfaction (Yu and Ramanathan, 2012). Based on theories of consumer behavior and cognitive psychology, several research projects have confirmed that corporate image is a critical factor for consumer satisfaction by the company (Lee and Lee, 2018).

Kant et al. (2017), empirically confirmed that there is an important relationship between corporate image and customer satisfaction. For this reason, they claimed that a satisfied customer base encourages and favors the corporate image, which in turn can affect the recurring customer support. Subsequently, Moorthy et al. (2018), determined that corporate image significantly influences customer satisfaction. The same conclusion was reached by Minkiewicz et al. (2011), finding that a positive corporate image can positively affect customer satisfaction. At the same time, other 
writers agree (Srivastava and Sharma, 2013). For this reason, the following hypothesis is proposed:

\section{H4: Corporate image has a positive impact on customer satisfaction.}

Customer satisfaction is an integrated concept that is shaped by customer experiences with a particular service, which is reflected by the extent to which customers are happy with the service. Satisfaction is seen as a result of customer experience in using a service and communicating with the service provider and is influenced by a variety of service-related factors such as service quality, age and gender. At the same time, satisfaction is known to be one of the key determinants of customer loyalty, which suggests that customers with a higher degree of satisfaction are more loyal to the service they receive (Park and Kim, 2018).

Acquiring a new customer is a more costly process for maintaining a customer. Customer loyalty is a critical business asset for long-term survival and competitive advantage. The concept of customer loyalty is seen as a combination of favorable attitudes leading to repurchase intentions and a good service (Onlaor and Rotchanakitumnuai, 2010). Famiyeh et al. (2018), define customer loyalty as the extent to which a customer has recurring behavior from a service provider, has a positive attitude towards the provider and considers that he only uses this provider when there is a need to obtain a service. It is widely accepted that customer satisfaction is a prerequisite for customer loyalty, which in turn affects profitability (Onlaor and Rotchanakitumnuai, 2010).

The marketing literature firmly recognizes customer satisfaction as a prerequisite for customer loyalty. The emotional judgments of satisfaction lead to the formation of an attitude that is integrated into the construction of customer loyalty (Carpenter, 2008). The positive effect of customer satisfaction on customer loyalty has been confirmed by several researchers (Alrubaiee and Nazer, 2010; Onlaor and Rotchanakitumnuai, 2010; Arikan and Güner, 2013; Martinez and Rodriguez del Bosque, 2013; Jani and Han, 2014; Kaura et al., 2015; Watson et al., 2015; Sharma, 2017; Famiyeh et al., 2018; Lee, 2018; Moorthy et al., 2018; Park and Kim, 2018). The correlation of customer satisfaction to customer loyalty has been explained by other authors (Hur et al., 2013; Shin and Thai, 2015), stressing that these two concepts are separate structures. They also reported that customer satisfaction is a good basis for their loyalty.

Customer satisfaction promotes loyalty and market resumption (Famiyeh et al., 2018). Through the excellent service quality it has been proven that customer satisfaction will lead to a great deal of customer loyalty. For this reason, the following hypothesis is proposed:

H5: Customer satisfaction has a positive impact on customer loyalty. 
Figure 1. Conceptual Framework

$\mathrm{H} 3$

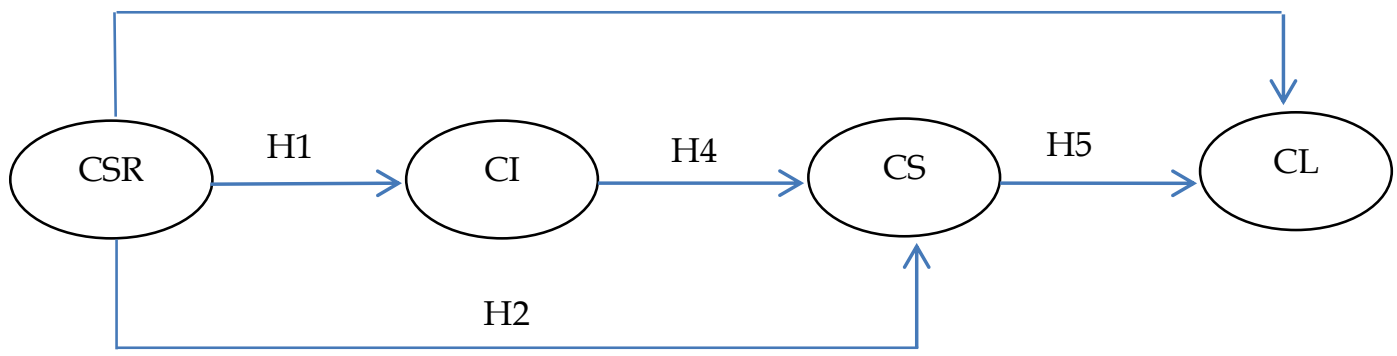

\section{Research Methods}

In order to testing the hypotheses formulated in the previous sections, a survey was contacted with the use of a structured questionnaire which consists of 41 items. Confirmatory factor analysis and Structural equation modeling technique was used to test and analyze the hypothetical relationships among the variables.

\subsection{Sample Data Collection}

Data collection was conducted using a structured questionnaire. For the distribution of the questionnaire, a form was constructed, in the Google drive application. A total of 358 mobile phone customers responded and the personal characteristics are presented in Table 1.

Table 1. Personal Characteristics

\begin{tabular}{|l|l|l|}
\hline \multicolumn{2}{|l|}{} & Percent \% \\
\hline \multirow{4}{*}{ Gender } & 1. Male & $36.3 \%$ \\
\cline { 2 - 3 } & 2. Female & $63.7 \%$ \\
\cline { 2 - 3 } & Total & $\mathbf{1 0 0 . 0 \%}$ \\
\hline \multirow{5}{*}{ Ege } & $1.18-25$ & $24.0 \%$ \\
\cline { 2 - 3 } & $2.26-35$ & $46.4 \%$ \\
\hline \multirow{5}{*}{ Oducational Level } & $3.36-50$ & $18.7 \%$ \\
\cline { 2 - 3 } & $4.50+$ & $10.9 \%$ \\
\cline { 2 - 3 } & Total & $\mathbf{1 0 0 . 0 \%}$ \\
\hline \multirow{5}{*}{ Occupation } & 1. Elementary & $5.9 \%$ \\
\cline { 2 - 3 } & 2. Secondary & $22.3 \%$ \\
\cline { 2 - 3 } & 3. University & $55.0 \%$ \\
\cline { 2 - 3 } & 4. MSc/PhD & $15.1 \%$ \\
\cline { 2 - 3 } & 5. Other & $1.7 \%$ \\
\cline { 2 - 3 } & Total & $\mathbf{1 0 0 . 0 \%}$ \\
\cline { 2 - 3 } & 1. Public employee & $24.3 \%$ \\
\cline { 2 - 3 } & 2. Private employee & $19.6 \%$ \\
\cline { 2 - 3 } & 3. Freelancer & $40.5 \%$ \\
\cline { 2 - 3 } & 4. Student & $10.3 \%$ \\
\hline
\end{tabular}




\begin{tabular}{|l|l|l|}
\hline & 5. Unemployed & $5.3 \%$ \\
\cline { 2 - 3 } & Total & $\mathbf{1 0 0 . 0 \%}$ \\
\hline
\end{tabular}

The most popular mobile communication company is, according to the respondents, Cosmote (32.7\%) and follow Vodafone (21.8), Q-Telecom (19.0\%), Wind (15.4\%) and Cyta (11.2\%).

\subsection{Questionnaire Description}

The research instrument of this study consists of 41 items divided in five sections. The first section, with 5 items, refers to the personal characteristics of the respondents. The second section with 16 items is related with the corporate social responsibility (C.S.R) of the mobile communication companies. The second section is divided in four subsections which are Customer (5 items), Employee (3 items), Community (4 items) and Environment (4 items). All the items are adopted from the work of Carroll (1999). The third section refers to the corporate image (C.I) consists of nine items, adopted from Nguyen $\kappa \alpha$ Leblanc (2001) and is divided in two subsections. The first one is named Functional (5 items) and the second Emotional (4 items). In the fourth section, for the evaluation of customer's satisfaction (C.S), the five items from the work of Cronin et al. (2000) were used. This section is divided in two subsections named Decision satisfaction (2 items) and Service satisfaction (3 items). Finally, the fifth section refers to the Customer' Loyalty (C.L), consist of six items adopted from the work of Zeithaml et al. (1996) and is divided in two subsections. The first is named Behavioral loyalty ( 3 items) and the second Attitudinal loyalty ( 3 items). All items, in the second, third, fourth and fifth section, were statements and the respondents were asked to indicate on a five- point Likert scale, ranging from $1=$ strongly disagree to $5=$ strongly agree, the degree to which they agreed with the statements.

\subsection{Validation of Research Instruments}

Several tests were performed to determine the content validity, the construct validity and the reliability of the questionnaire used in the present survey. These tests are necessary to ensure the suitability of the research tool.

The first performed test was about the content validity. This test examines if the instrument covers the entire domain associated with the variable that is designed for the specific measurement (Heale and Twycross, 2015). In order to ensure the content validity of this research, a review of the literature on the subject of the study was initially carried out, and secondly, a pilot study was carried out on a group of experts (professors and practitioners). In our study, all variables were used in a similar survey and were considered valid.

The next step in the validation procedure was the construct validity test. The construct validity seeks on agreement between a theoretical concept and a specific 
measuring device or procedure. Cao and Dowlatshahi (2005) suggest three ways to assess construct validity: (1) a test of Unidimensionality, (2) a test of Convergent validity and (3) a test of Discriminant validity.

Unidimensionality gives evidence of a single latent construct (Flynn et al., 1990). There are two methods for evaluating the unidimentionality of a measure: exploratory factor analysis (EFA) and confirmatory factor analysis (CFA). This study uses CFA because items from similar studies are used and the structure of the model is defined a priori.

Four Confirmatory factor analyses were performed one for each section of our study (16 items of corporate social responsibility, 9 items of corporate image, 5 items of customer satisfaction and 6 items of customer loyalty). In CFA the factorial models were evaluated for overall and measurement model fit. A statistical non-significant value of $\chi^{2}$-statistics ( $p$-value $>0.05$ ), a value of Root Mean Square Error of Approximation (RMSEA) less than 0.1 and a value of Comparative Fit Index (CFI) and Goodness of Fit Index greater than 0.90 indicate a good overall fit of the data in the proposed model (Kline, 1998). In the case in which the value of $\chi^{2}$ statistics is significant ( $\mathrm{p}$-value $<0.05$ ), something that happens almost always in big samples $(\mathrm{n}>200)$, the index $\chi^{2} / \mathrm{d}$.f is used and a value bigger the 1 and smaller the 3 , as propose Hair et al. (2010) is satisfactory. Significant path coefficients, Composite Reliability (C.R) greater than the benchmark of 0.7 and Average Variance Extracted (A.V.E) higher than 0.5 (Fornell and Larcker, 1981) indicates good fit of the data in the measurement model.

All the CFA which were performed indicated good overall fit of the data to the proposed models. Moreover, all the path coefficients are significant and the C.R and A.V.E take values greater than 0.7 and 0.5 respectively, as Fornell and Lacker (1981) suggest, indicating the convergent validity and the ideal fit of the measurement models. To assess the reliability of the constructs, which measures the internal consistency, the C.R was used, and in all the constructs it was greater than the suggesting cut- off point of 0.7 (Fornell and Lacker, 1981).

Discriminant validity copes with the concept that differing constructs should be dissimilar (Burns and Bush, 1995). An indicator of discriminant validity can be found if the squared correlation coefficients of each construct pair are smaller than the AVEs (Hair et al., 2010). The results of discriminant validity test, suggesting discrimination validity of the constructs.

\section{Data Analysis and Results}

The mean score of the four constructs shows that customers appreciate more the corporate image of the companies (3.73), followed by customer loyalty (3.64), customer satisfaction (3.54) and corporate social responsibility (3.29). 
Table 2. Mean and Standard Deviation of the constructs

\begin{tabular}{|l|l|l|}
\hline Constructs & Mean & Std. Deviation \\
\hline Corporate Social Responsibility & 3.29 & 0.646 \\
\hline Corporate Image & 3.73 & 0.798 \\
\hline Customer Satisfaction & 3.54 & 0.897 \\
\hline Customer Loyalty & 3.64 & 0.916 \\
\hline
\end{tabular}

The analysis of variance (ANOVA) on gender, age, education, occupation and preferred mobile company the respondents surveyed showed no statistically significant difference on the group means of Corporate Social Responsibility. On the other hand ANOVA, showed statistically significant difference of Corporate Image, Customer Satisfaction and Customer Loyalty on Education, Occupation and Mobile Company.

Table 3. Results from ANOVA

\begin{tabular}{|l|l|l|l|l|l|l|}
\hline & \multicolumn{3}{|l|}{ Education } & \multicolumn{2}{l|}{ Occupation } & \multicolumn{2}{l|}{ Mobile Company } \\
\hline Constructs & F & Sig. & F & Sig. & F & Sig. \\
\hline Corporate Image & 4.630 & 0.001 & 3.770 & 0.005 & 6.085 & 0.000 \\
\hline Customer Satisfaction & 3.837 & 0.005 & 4.190 & 0.003 & 6.170 & 0.000 \\
\hline Customer Loyalty & 3.094 & 0.016 & 4.142 & 0.003 & 4.241 & 0.002 \\
\hline
\end{tabular}

\subsection{Hypotheses Testing}

In order to testing the hypotheses the Structural Equation Modeling (S.E.M) technique was used and the overall model, the measurement model and the structural model assessed. The results on the table 12 indicate an ideal fit of the overall model and measurement model and moreover its constructs have reliability, convergent validity and discriminant validity.

Table 4. Results from Structural Equation Model

\begin{tabular}{|c|c|c|c|c|}
\hline Items & Loadings & Factors & $\begin{array}{l}\text { Composite } \\
\text { Reliability }\end{array}$ & $\begin{array}{l}\text { Average } \\
\text { Variance } \\
\text { Extracted }\end{array}$ \\
\hline Customer & 0.82 & \multirow{4}{*}{$\begin{array}{l}\text { Corporate Social } \\
\text { Responsibility }\end{array}$} & \multirow{4}{*}{0.887} & \multirow{4}{*}{0.664} \\
\hline Employee & 0.81 & & & \\
\hline Community & 0.83 & & & \\
\hline Environment & 0.80 & & & \\
\hline Functional & 0.83 & \multirow{2}{*}{ Corporate Image } & \multirow{2}{*}{0.886} & \multirow{2}{*}{0.796} \\
\hline Emotional & 0.95 & & & \\
\hline Decision & 0.90 & \multirow{2}{*}{$\begin{array}{l}\text { Customer } \\
\text { Satisfaction }\end{array}$} & \multirow{2}{*}{0.906} & \multirow{2}{*}{0.828} \\
\hline Service & 0.92 & & & \\
\hline Behavioral & 0.88 & \multirow{2}{*}{ Customer Loyalty } & \multirow{2}{*}{0.912} & \multirow{2}{*}{0.838} \\
\hline Attitudinal & 0.95 & & & \\
\hline
\end{tabular}




$$
\begin{array}{ll}
\chi^{2}=83.29 & \text { RMSEA }=0.091 \\
\mathrm{df}=28 & \text { CFI }=0.98 \\
\chi^{2} / \mathrm{df}=2.97<3 & \\
\mathrm{p}-\text { value }=0.000 & \text { AGFI }=0.81
\end{array}
$$

$\mathrm{GFI}=0.90$

Table 5. Test of Discriminant Validity of the constructs

\begin{tabular}{|l|l|l|l|l|}
\hline & CSR & CI & CS & CL \\
\hline Corporate Social Responsibility & $\mathbf{0 . 6 6 4}$ & & & \\
\hline Corporate Image & 0.439 & $\mathbf{0 . 7 9 6}$ & & \\
\hline Customer Satisfaction & 0.391 & 0.695 & $\mathbf{0 . 8 2 8}$ & \\
\hline Customer Loyalty & 0.289 & 0.632 & 0.670 & $\mathbf{0 . 8 3 3}$ \\
\hline
\end{tabular}

Note: AVE of each construct is shown in bold.

Figure 2 shows the structural model with a path diagram showing the standardized coefficients for each hypothesized relationship. Hypotheses testing show that hypothesis $\mathrm{H} 3$ is not supported as the path coefficient is not significant $(\gamma=0.09)$. All the other hypotheses are supported. C.S.R has a significant positive effect on C.I $(\gamma=0.71)$ and C.S $(\gamma=0.14)$, C.I has a significant positive effect on C.S $(\gamma=0.79)$ and finally C.S has a strong positive and significant effect on C.L $(\gamma=0.73)$.

Figure 2. The Structural Model

$\mathrm{H} 3$

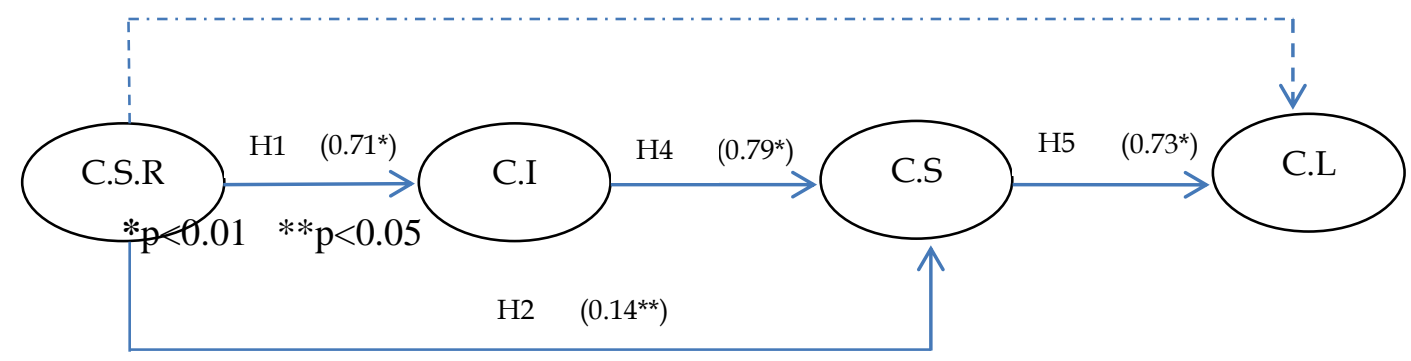

The structural model shows that C.S.R has a strong positive effect on C.I, while the effect of C.S.R on C.S even if it is positive it is very small. However, the most important finding of the study is that the effect of C.S.R on C.L seems to be no significant. In an attempt to define what of the four subfactors of corporate social responsibility affects more the customers' loyalty a multiple regression analysis was performed and the results indicate that only the subfactor "customer" has a significant and positive effect on customers' loyalty. In simple words, the customers appreciate more the practices of corporate social responsibility from which they takes the maximum satisfaction. 
Table 6. Results of Regression Analysis

\begin{tabular}{|l|l|l|l|l|}
\hline Independent Variables & Beta & t & Sig. & V.I.F \\
\hline Customer & 0.558 & 9.096 & 0.000 & 2.128 \\
\hline Employee & 0.032 & 0.439 & 0.222 & 2.362 \\
\hline Community & 0.120 & 1.693 & 0.091 & 2.836 \\
\hline Environment & -0.074 & -1.082 & 0.280 & 2.653 \\
\hline \multicolumn{7}{|l}{} \\
& $\begin{array}{l}\mathrm{F}=53.352 \\
\mathrm{R}^{2}=0.377 \text { Sig. }=0.000\end{array}$ \\
\hline
\end{tabular}

To understand why no direct relationship exists between CSR and CL (H3), a further study is conducted for examining the possible mediating effect of customer satisfaction (C.S) in the context of the structural model. To test the mediating effect of a mediator variable between an independent and a dependent variable is needed first of all to ensure that the variables are correlated. In Table 5 are indicated the square correlations between each construct pair. A variable works as mediator in a relationship between two other variables if meets the following conditions (Baron and Kenny, 1986): (a) the independent variable (CSR) has a significant effect on the dependent variable (CL), (b) the independent variable (CSR) has a significant effect on the mediator (C.S), (c) the mediator (C.S) has a significant effect on the dependent variable (CL) and (d) the previously significant effect of independent variable (CSR) on the dependent variable (CL) is no longer significant when the mediator (C.S) is introduced in the in the causal pathway between the two (CSR and CL). The path coefficients between CSR and CL is $0.538(\mathrm{p}=0.000)$, between CSR and CS is $0.626(\mathrm{p}=0.000)$ and between CS and CL is $0.819(\mathrm{p}=0.000)$. When CS is introduced between CSR and CL the change of the path coefficient between CSR and CL from 0.528 to $0.059(\mathrm{p}=0.290)$ indicates that the mediating effect of customer satisfaction is quite strong. This result suggests that CSR would help strengthen a mobile phone company's customer loyalty through the mediating effect of customer satisfaction.

\section{Conclusions, Managirial Implications, Limitations}

Every business (private or public, organization or non-governmental organization), in order to establish itself, to become better known in its field and to build its image, uses various methods and develops various activities such as advertising, public relations and in the recent years corporate social responsibility that has been a concept increasingly associated with the corporate image over the last decade. Social responsibility promotes corporate responsibility, social awareness, sensitivity, awareness and business ethics. CSR has a positive impact on shaping corporate image and reputation. Consumers demand respect policies, as companies are more easily appraised than in the future. Because consumers are attracted to ethical practices, they are more likely to contribute to further business profitability. So establishing a positive image of business between commercial entities, non- 
governmental organizations, the educational world, local communities and the public sector can only positively impact company influence and dominance.

The findings of this study indicate that Corporate Social Responsibility have not a significant direct effect on Customer loyalty, while corporate image and customer satisfaction have a significant positive effect on customer loyalty. These results coincide with the results of similar surveys conducted in the tourism (RevillaCamacho et al., 2017), and transport (Chang and Yeh, 2017) sectors. Moreover, the findings provide practical new insights in understanding how a mobile company's CSR policy could be developed and implemented to help enhance customer loyalty through the mediating effects of corporate image and customer satisfaction. It is understood that the Greek customers of the mobile companies give more value to their satisfaction from the services provided by the companies, while the companies do not manage to disseminate their CSR practices in a credible way.

This study is a pioneer research in addressing the mediating role played by corporate image and customer satisfaction for strengthening the relationship between CSR and customer loyalty in mobile phone companies. The companies would like to understand the implications of its CSR policy implementation, especially in enhancing its corporate image and customer satisfaction in terms of reputation and impression. Managers must communicate the CSR practices which they carry out. An intelligent communication of CSR will affirm the company's credibility and honesty. This communication should not only be through websites and CR reports, but also via other means of communication which reach different age segments. Despite these contributions, this study has limitations due to the survey data collected and the method used. The sample of this study is constrained by the customers of Kavala town only and in a future research could be present customers from all the country and from different sectors.

\section{References:}

Ailawadi, K.L., Neslin, S.A., Luan, Y.J. אaı Taylor, G.A. 2014. Does retailer CSR enhance behavioral loyalty? A case for benefit segmentation. International Journal of Research in Marketing, 31 (2), 156-167.

Alrubaiee, L. and Al-Nazer, N. 2010. Investigate the impact of relationship marketing orientation on customer loyalty: The customer's perspective. International Journal of Marketing Studies, 2(1), 155-174.

Anthony, R., Bean, J., Coyle, J., Hayward, G. and James, K. 2011. Sustainability Assessment of the Mobile Service Industry. https://www.slideshare.net/kellyhautjames/mobileservices-industry.

Aramburu, I.A. and Pescador, I.G. 2019. The Effects of Corporate Social Responsibility on Customer Loyalty: The Mediating Effect of Reputation in Cooperative Banks Versus Commercial Banks in the Basque Country. Journal of Business Ethics, 154(3), 701.

Arendt, S. and Brettel, M. 2010. Understanding the influence of corporate social responsibility on corporate identity, image, and firm performance. Management Decision, 48(10), 1469-1492. 
Arikan, E. and Güner, S. 2013. The impact of corporate social responsibility, service quality and customer-company identification on customers. Procedia - Social and Behavioral Sciences, 99, 304-313.

Berle, A. אal Means, G. 1932. The Modern Corporation and Private Property. Transaction Publishers, New Jersey.

Bolton, L.E. and Mattila, A.S. 2015. How Does Corporate Social Responsibility Affect Consumer Response to Service Failure in Buyer-Seller Relationship? Journal of Retailing, 91(1), 140-153.

Bowen, H.R. 1953. Social Responsibilities of the Businessman. Harper, Michigan.

Branco, M.C. and Rodrigues, L.L. 2006. Corporate social responsibility and resource-based perspectives. Journal of Business Ethics, 69(2), 111-132.

Burns, A.C. and Bush, R.F. 1995. Marketing research. Englewood Cliffs, NJ, Prentice-Hall.

Cao, Q. and Dowlatshahi, S. 2005. The impact of alignment between virtual enterprise and information technology on business performance in an agile manufacturing environment. Journal of Operations Management, 23, 531-550.

Carroll, A.B. 1999. Corporate social responsibility: evolution of a definitional construct. Business and Society, Vol. 38, No. 3, 268-295.

Carpenter, J.M. 2008. Consumer shopping value, satisfaction and loyalty in discount retailing. Journal of Retailing and Consumer Services, 15(5), 358-363.

Chang, Y.H. and Yeh, C.H. 2017. Corporate social responsibility and customer loyalty in intercity bus services. Transport Policy, 59, 38-45.

Chung, K.H., Yu, J.E., Cuk-Choi, M., kal Shin, J. 2015. The effects of CSR on customer satisfaction and loyalty in China: The moderating role of corporate image. Journal of Economics, Business and Management, 3(5), 542-547.

Cronin Jr., J.J., Brady, M.K. and Hult, G.T.M. 2000. Assessing the effects of quality, value, and customer satisfaction on consumer behavioral intentions in service environments. Journal of Retailing, Vol. 76, No. 2, 193-218.

Da Giau, A., Macchion, L., Caniato, F., Caridi, M., Danese, P., Rinaldi, R. and Vinelli, A. 2016. Sustainability practices and web-based communication: an analysis of the Italian fashion industry. Journal of Fashion Marketing and Management, 20(1), 72-88.

Famiyeh, S., Kwarteng, A. and Asante-Darko, D. 2018. Service quality, customer satisfaction and loyalty in automobile maintenance services: Evidence from a developing country. Journal of Quality in Maintenance Engineering, 24(3), 262-279.

Fatma, M., Rahman, Z. and Khan, I. 2015. Building company reputation and brand equity through CSR: the mediating role of trust. International Journal of Bank Marketing, 33 (6), 840-856.

Flynn, B.B., Sakakibara, S., Schroeder, R.G., Bates, K.A., Flynn, E.J. 1990. Empirical research methods in operations manage- ment. J. Operations Manage, 9(2), 250-284.

Fordham, A.E., Robinson, G.M. and Leeuwen, J.V. 2018. Developing community based models of Corporate Social Responsibility. Extractive Industries and Society, 5(1), 131-143.

Fornell, C. and Larcker, D.F. 1981. Evaluating Structural Equation Models with Unobservable Variables and Measurement Error. Journal of Marketing Research, Vol. 18, No. 1, 39-50.

Galbreath, J. 2010. How does corporate social responsibility benefit firms? Evidence from Australia. European Business Review, 22(4), 411-431.

Garcia de los Salmones, M.M., Perez, A. אal Rodriguez del Bosque, I. 2009. The social role of financial companies as a determinant of consumer behavior. International Journal of Bank Marketing, 27(6), 467-485. 
Gupta, S. and Pirsch, J. 2008. The influence of a retailer's corporate social responsibility program on reconceptualizing store image. Journal of Retailing and Consumer Services, 15(6), 516-526.

Hair, F., Anderson, R., Tatham, R. and Black, W. 2010. Multivariate Data Analysis with Readings. Prentice-Hall International, London.

He, H. and Li, Y. 2011. CSR and Service Brand: The Mediating Effect of Brand Identification and Moderating Effect of Service Quality. Journal of Business Ethics, 100(4), 673-688.

Heale, R. and Twycross, A. 2015. Validity and reliability in quantitative research. EvidenceBased Nursing, Vol. 18, No. 3, 66-67.

Hossain, M.M., Alamgir, M. and Alam, M. 2016. The mediating role of corporate governance and corporate image on the CSR-FP link: Evidence from a developing country. Journal of General Management, 41(3), 33-51.

Hsu, K.T. 2012. The advertising effects of corporate social responsibility on corporate reputation and brand equity: evidence from the life insurance industry in Taiwan. Journal of Business Ethics, 109(2), 189-201.

Huang, C.C., Yen, S.W., Liu, C.Y. and Huang, P.C. 2014. The relationship among corporate social responsibility, service quality, corporate image and purchase intention. International Journal of Organizational Innovation, 6(3), 68-84.

Huang, C.F. and Lien, H.C. 2012. An empirical analysis of the influences of corporate social responsibility on organizational performance of Taiwan's construction industry: Using corporate image as a mediator. Construction Management and Economics, 30(4), 263-275.

Hur, W.M., Kim, Y. and Park, K. 2013. Assessing the effects of perceived value and satisfaction on customer loyalty: A 'green' perspective. Corporate Social Responsibility and Environmental Management, 20(3), 146-156.

Jani, D. and Han, H. 2014. Personality, satisfaction, image, ambience, and loyalty: Testing their relationships in the hotel industry. International Journal of Hospitality Management, 37, 11-20.

Kadlubek, M. 2015. The essence of corporate social responsibility and the performance of selected company. Procedia - Social and Behavioral Sciences, 213, 509-515.

Kant, R., Jaiswal, D. and Mishra, S. 2017. The Investigation of Service Quality Dimensions, Customer Satisfaction and Corporate Image in Indian Public Sector Banks: An Application of Structural Equation Model (SEM). The Journal of Business Perspective, 2(1), 1-10.

Kaura, V., Prasad, C.S. and Sharma, S. 2015. Service quality, service convenience, price and fairness, customer loyalty, and the mediating role of customer satisfaction. International Journal of Bank Marketing, 33(4), 404-422.

Kline, R.B. 1998. Principles and Practices of Structural Equation Modeling. New York: The Guilford Press.

Kotler, P. and Amstrong, G. 2008. Principles of marketing (12th ed.), Upper Saddle River, New Jersey.

Lai, C.S., Chiu, C.J., Yang, C.F. and Pai, D.C. 2010. The effects of corporate social responsibility on brand performance: the mediating effect of industrial brand equity and corporate reputation. Journal of Business Ethics, 95(3), 457-469.

Lau, A.K.W., Lee, P.K.C. and Cheng, T.C.E. 2018. An empirical taxonomy of corporate social responsibility in China's manufacturing industries. Journal of Cleaner Production, 188, 322-338. 
Lee, C.Y. 2018. Does Corporate Social Responsibility Influence Customer Loyalty in the Taiwan Insurance Sector? The role of Corporate Image and Customer Satisfaction. Journal of Promotion Management, 25(1), 43-64.

Lee, J. and Lee, Y. 2018. Effects of multi-brand company's CSR activities on purchase intention through a mediating role of corporate image and brand image. Journal of Fashion Marketing and Management, 22(3), 387-403.

Lee, S. and Heo, C.Y. 2009. Corporate social responsibility and customer satisfaction among US publicly traded hotels and restaurants. International Journal of Hospitality Management, 28(4), 635-637.

Liu, Y. and Zhou, X.2009. Corporate social responsibility and customer loyalty: A conceptual framework. Proceedings of the $20096^{\text {th }}$ International Conference on Service Systems and Service Management, ICSSSM '09 5174989, 794-798.

Lombart, C. and Louis, D. 2014. A study of impact of corporate social responsibility and price image on retailer personality and consumers' reaction-satisfaction, trust and loyalty to the retailer. Journal of Retailing and Consumer Services, 21(4), 630-642.

Loureiro, S.M.C., Dias Sardinha, I.M. and Reijnders, L. 2012. The effect of corporate social responsibility on customer satisfaction and perceived value: The case of the automobile industry sector in Portugal. Journal of Cleaner Production, 37, 172-178.

Lu, X., Liu, H.W. and Rahman, M. 2017. The impact of corporate social responsibility on customer loyalty: A case for two global corporations in China. Strategic Change, 26(3), 251-260.

Luo, X. and Bhattacharya, C.B. 2006. Corporate social responsibility, customer satisfaction, and market value. Journal of Marketing, 70(4), 1-18.

Macchion, L., Da Giau, A., Caniato, F., Caridi, M., Danese, P., Rinaldi, R. and Vinelli, A. 2018. Strategic approaches to sustainability in fashion supply chain management. Production Planning \& Control, 29(1), 9-28.

Mandhachitara, R. and Poolthong, Y. 2011. A model of customer loyalty and corporate social responsibility. Journal of Services Marketing, 25(2), 122-133.

Martinez, P. and Rodriguez del Bosque, I. 2013. CSR and customer loyalty: The roles of trust, customer identification with the company and satisfaction. International Journal of Hospitality Management, 35, 89-99.

Minkiewicz, J., Evans, J., Bridson, K. and Mavondo, F. 2011. Corporate image in the leisure services sector. Journal of Services Marketing, 25(3), 190-201.

Moktadir, A., Rahman, T., Jabbour, C.J.C., Mithun Ali, S. and Kabir, G. 2018. Prioritization of drivers of corporate social responsibility in the footwear industry in an emerging economy: A fuzzy AHP approach. Journal of Cleaner Production, 201, 369-381.

Moorthy, K., Chun T'ing, L., Ai Na, S., Sze Xian, L. and Wei Ling, T. 2018. Corporate image no longer leads to customer satisfaction and loyalty: a Malaysian perspective. International Journal of Law and Management, 60(4), 934-952.

Mubarak, A.Z., Hamed, B.A. and Mubarak, A.M. 2018. Impact of corporate social responsibility on bank's corporate image. Social Responsibility Journal.

Nguyen, N., and Leblanc, G. 2001. Corporate image and corporate reputation in customers' retention decisions in services. Journal of Retailing and Consumer Services, 8(4).

Onlaor, W. and Rotchanakitumnuai, S. 2010. Enhancing Customer Loyalty towards Corporate Social Responsibility of Thai Mobile Service Providers. World Academy of Science, Engineering and Technology, 42, 1560-1564.

Pang, A., Lwin, M.O., Ng, C.S.M., Chau, S.R.W.C. and Yeow, K.P.S. 2018. Utilization of CSR to build organizations' corporate image in Asia: need for an integrative approach. Asian Journal of Communication, 28(4), 335-359. 
Park, E. and Kim, K.J. 2018. What drives "customer loyalty"? The role of corporate social responsibility. Sustainable Development, 1-8.

Perez, A. and Rodriguez del Bosque, I. 2015. Corporate social responsibility and customer loyalty: Exploring the role of identification, satisfaction and type of company. Journal of Services Marketing, 29(1), 15-24.

Revilla-Camacho, M.A., Cossio-Silva, F.J., Palacios-Florencio, B. 2017. Corporate Responsibility under the ECSI model: An application in the hotel sector. European Research on Management and Business Economics, 23(1), 23-32.

Qu, R. 2014. Market Orientation and Organizational Performance Linkage in Chinese Hotels: The Mediating Roles of Corporate Social Responsibility and Customer Satisfaction. Asia Pacific Journal of Tourism Research, 19(12), 1399-1416.

Sharma, V.K. 2017. Patient satisfaction and brand loyalty in healthcare organizations in India. Journal of Asia Business Studies, 11(1), 73-87.

Shin, Y. and Thai, V.V. 2015. The Impact of Corporate Social Responsibility, Customer Satisfaction, Relationship Maintenance and Loyalty in the Shipping Industry. Corporate Social Responsibility and Environmental Management, 22(6), 381-392.

Servaes, H. and Tamayo, A. 2013. The impact of corporate social responsibility on firm value: The role of customer awareness. Management Science, 59(5), 1045-1061.

Srivastava, K. and Sharma, N.K. 2013. Service Quality, Corporate Brand Image, and Switching Behavior: The Mediating Role of Customer Satisfaction and Repurchase Intention. Services Marketing Quarterly, 34(4), 274-291.

Stanaland, A.J.S., Lwin, M.O. and Murphy, P.E. 2011. Consumer perceptions of the antecedents and consequences of corporate social responsibility. Journal of Business Ethics, 102(1), 47-55.

Swaen, V. and Chumpitaz, R.C. 2008. Impact of corporate social responsibility on consumer trust. Recherche et Applications en Marketing, 23(4), 7-34.

Turnbull, P.W., Leek, S. and Ying, G. 2000. Customer Confusion: The Mobile Phone Market. Journal of Marketing Management, 16(1-3), 143-163.

Vilanova, M., Lozano, J.M. and Arenas, D. 2009. Exploring the nature of the relationship between CSR and competitiveness. Journal of Business Ethics, 87(1), 57-69.

Watson, G.F., Beck, J.T., Henderson, C.M. and Palmatier, R.W. 2015. Building, measuring, and profiting from customer loyalty. Journal of the Academy of Marketing Science, 43(6), 790-825.

Whait, R.B., Christ, K.L., Ortas, E. and Burritt, R.L. 2018. What do we know about tax aggressiveness and corporate social responsibility? An integrative review. Journal of Cleaner Production, 204, 542-552.

Xie, X., Jia, Y., Meng, X. and Li, C. 2017. Corporate social responsibility, customer satisfaction, and financial performance: The moderating effect of the institutional environment in two transition economies. Journal of Cleaner Production, 150, 26-39.

Yu, W. and Ramanathan, R. 2012. Retail service quality, corporate image and behavioural intentions: the mediating effects of customer satisfaction. International Review of Retail, Distribution and Consumer Research, 22(5), 485-505.

Yuen, K.F., Thai, V.V. and Wong, Y.D. 2018. An investigation of shippers' satisfaction and behaviour towards corporate social responsibility in maritime transport.

Transportation Research Part A: Policy and Practice, 116, 275-289.

Zeithaml, V.A., Berry, L.L. and Parasuraman, A. 1996. The behavioral consequences of service quality. Journal of Marketing, Vol. 60, No. 2, 31-46. 